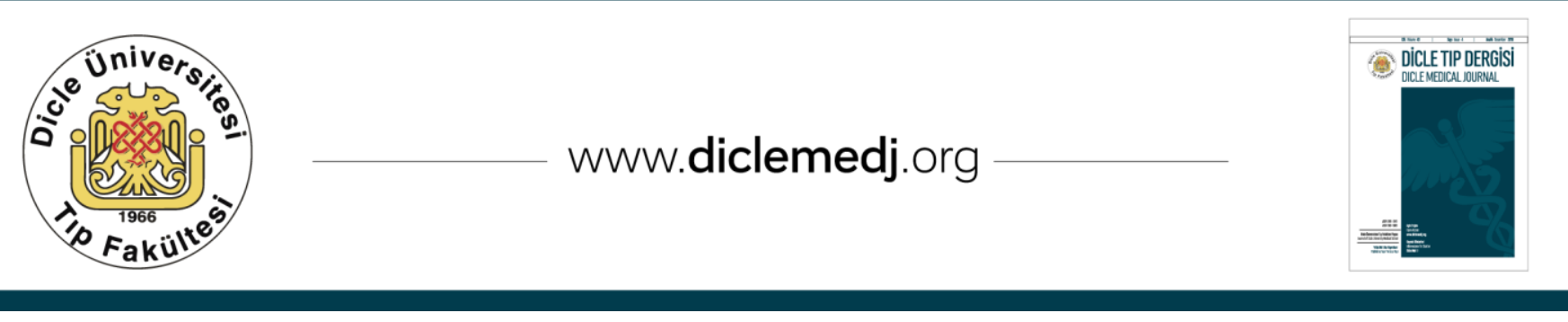

Olgu Sunumu / Case Report

\title{
Spillage and recurrence in surgical management of hydatid cyst of the liver
}

\author{
Ulaş Aday ${ }^{1}$, Abdullah Böyük ${ }^{2}$ \\ 1 Dept of Gastroenterological Surgery, Univ of Health Sciences, Elazıg Training and Research Hospital, Elazıg, Turkey 0RCID: 0000-0002-3161-0923 \\ 2 Department of Surgery, University of Health Sciences, Elazıg Training and Research Hospital, Elazıg, Turkey ORCID: 0000-0003-0628-9303
}

Received: 11.03.2019; Revised: 08.04.2019; Accepted: 20.06.2019

\begin{abstract}
Recurrence remains a serious problem in hydatid disease (HD) despite the advancements in treatment modalities. Spillage of cyst material during conservative treatment can result in extrahepatic multifocal recurrence. In the surgical management of recurrent cysts associated with procedure-related spillage, the procedure is further complicated by the multifocal nature of these cysts and the adhesions caused by prior surgery, thereby leading to increased risk of morbidity and recurrence.

There fore, utmost care should be taken to prevent spillage during the primary surgery. In this report, we present a 64-year-old female patient who underwent surgical treatment due to multifocal, symptomatic, recurrent hydatid cysts associated with procedure-related spillage. Total cystectomy was performed for the cysts in the abdominal wall and in the intraabdominal and subdiaphragmatic areas while partial cystectomy with drainage and omentoplasty were performed for the cysts in the liver parenchyma.

The recurrence risk can be reduced via perioperative albendazole treatment, complete resection of the cyst without perforation, protection of adjacent anatomical structures by the use of scolicidal agent-soaked sponges, and meticulous surgical treatment leaving no residual cyst material.
\end{abstract}

Keywords: liver, hydatid cyst, spillage, recurrence.

DOI: 10.5798/dicletip.620672

Yazışma Adresi / Correspondence: Ulaş Aday, Department of Gastroenterological Surgery University of Health Sciences, Elazıg Training and Research Hospital RızaiyeMh.,İönü Cad. No: 74, 23200, Elazığ, Turkey e_mail: ulasaday@gmail.com 


\section{Karaciğer hidatik kist cerrahisinde dökülme ve nüks}

Öz

Tedavi modalitelerindeki gelişmelere rağmen kist hidatik hastalığında nüks önemini korumaktadır. Konservatif cerrahi esnasında kist elamanlarının dökülmesi (spillage) extrahepatikmultifokalnükslerle sonuçlanabilir. Nüks vakalarda adezyonlar ve multifokal kistler nedeniyle cerrahi prosedür kompleksleşir, morbidite ve nüks oranları artar. Bu nedenle primer cerrahi esnasında dökülmelerin önlenmesine yönelik tüm tedbirler alınmalıdır. Altmış dört yaşında kadın hastada spillage nedeniyle gelişen multifokal, semptomatiknükshidatik kist nedeniyle cerrahi tedavi uygulandı. Abdominal duvar, intrabdominal, subdiafragmatik kistlere total kistektomi, karaciğerdeki kiste parasiyelkistektomi+drenaj+omentoplasti yapıldı. Perioperatifalbendazol kullanımı, kistte rüptüroluşturulmaması, cerrahi alanın skolosidal ajanlarca korumaya alınması ve rezidü kist elamanlarının bırakılmaması nüks gelişimini önlemede oldukça önemlidir.

Anahtar kelimeler: karaciğer, hidatik kist, dökülme, nüks.

\section{INTRODUCTION}

Hydatid disease (HD) is a common public health problem frequently seen in the regions around the world where live animal husbandry is the primary source of living. Turkey is geographically part of the Middle East where HD is endemic. Larvae of small sizes pass through the hepatic filtration system and travel to the lungs. Therefore, liver (70\%) and lungs $(20 \%)$ are the most commonly involved organs in $\mathrm{HD}^{1,2}$. HD recurrence is a significant problem during the long-term follow-up of the disease. The incidence of recurrence after surgery for hydatid cyst of the liver is around $10 \%^{3-5}$.

Local recurrence occurs following surgical or radiological intervention and presents as reappearance of live cysts at the site of a previously treated cyst or the emergence of a novel extrahepatic disease caused by procedure-related spillage. Meaningfully, protection of the surgical site from cystic contents and mechanical clearance of whole alive cystic material are of vital importance for the prevention of recurrence ${ }^{6,7}$. In this case report, we aimed to emphasize the importance of spillage that caused intrahepatic, intraabdominal, and abdominal wall recurrence in a patient who underwent surgical treatment due to primary hepatic hydatid cyst two years earlier.

\section{CASE}

A 64-year-old female patient presented to our clinic with a right upper quadrant pain. The patient had an 8-year history of diabetes mellitus (DM) and was on oral antidiabetic therapy, and had undergone surgical treatment for symptomatic hepatic hydatid cyst in an outer center two years earlier. One year after surgery, the patient had intrahepatic and intraabdominal recurrence and was initiated on a 3-month albendazole therapy.

Over the last one month, the patient suffered from worsening pain in the right upper quadrant and subcostal incision line. Physical examination revealed a palpable $\sim 3-\mathrm{cm}$ mass in the muscular tissue inferior-lateral to the subcostal incision line. Laboratory parameters were normal except for fasting blood glucose $(128 \mathrm{mg} / \mathrm{dl})$. Contrast-enhanced computed tomography (CT) revealed multiple impressions suggestive of hydatid cyst in several anatomical fields including right posterior hepatic lobe, posterior subdiaphragmatic area, intraperitoneal space, upper right quadrant of the abdominal cavity, and abdominal muscle tissues (Figures 1, 2, 3). The patient was scheduled for surgical treatment of symptomatic hydatid cyst due to inadequate response to the albendazole therapy. For 10 days prior to the surgery, the patient received albendazole $10 \mathrm{mg} / \mathrm{kg} /$ day in 
two divided doses. The patient was informed about the surgical procedure and a verbal and written consent was obtained from the patient.

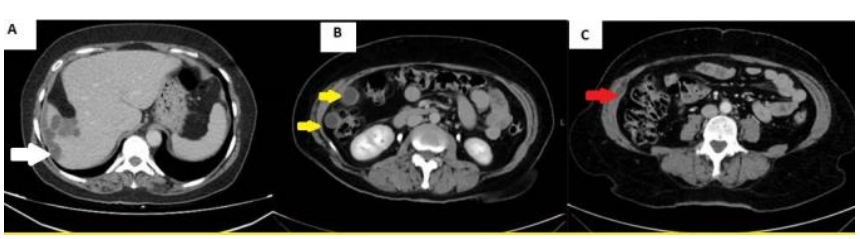

Figure 1 A-C. Axial CT images showing cysts in the liver (A), intraabdominal area (B), and abdominal wall (C).

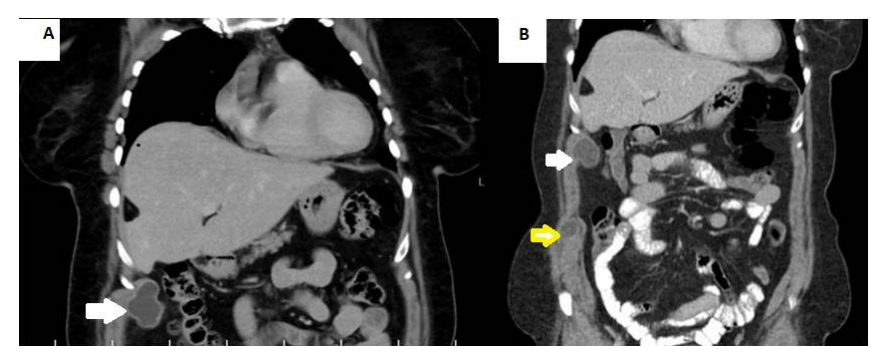

Figure 2 A-B. Coronal CT images showing cysts in the abdominal wall (A) and parietal peritoneum (B).

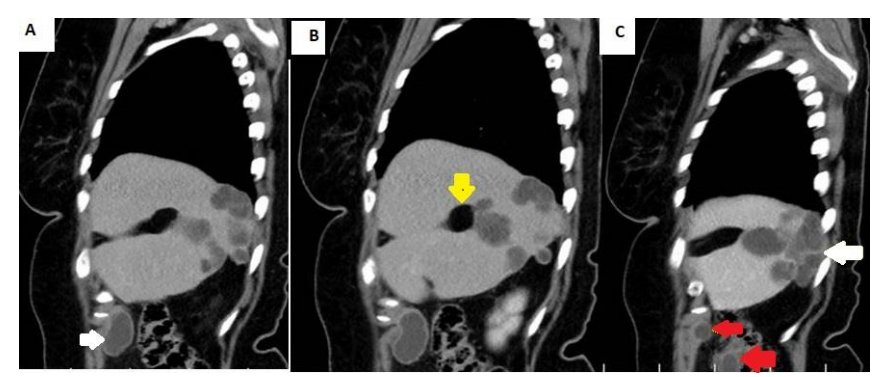

Figure 3 A-C. Sagittal CT images of the cysts. The falciform flap (B) used in prior surgery is indicated by a yellow arrow

Under general anesthesia, a midline incision was made from the xiphoid to the umbilicus and was extended to the right subcostal area to secure an adequate surgical field of view. The omental and bowel adhesions in the right upper quadrant caused by previous cholecystectomy were dissected. The falciform ligament that had been used as a flap in the cyst site during prior surgery was exposed. Recurrent hydatid cysts were observed in the space between the hepatic flexure and liver, parietal peritoneum lining the right lateral abdominal wall, liver segment VII, right subdiaphragmatic area, and within the abdominal muscle groups. The surgical field was protected using hypertonic saline-soaked sponges. Total cystectomy was performed for the cysts in the abdominal wall (Figure 4) and in the intraabdominal and subdiaphragmatic areas while partial cystectomy with drainage and omentoplasty were performed for the cysts in the liver parenchyma (Figures 5,6 ). Due to dense adhesions around the subdiaphragmatic cyst, partial diaphragm resection was performed and a chest tube was inserted. The procedure was completed following the inspection of the liver parenchyma for residual cyst material via intraoperative ultrasonography (USG). The patient had no postoperative complication and was discharged uneventfully on postoperative day8. Postoperative albendazole therapy was continued for three months. At one-year followup, the patient had no signs of recurrence.

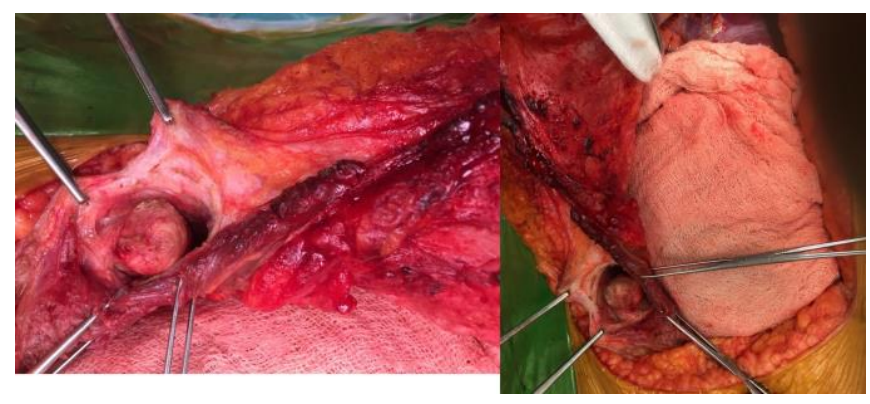

Figure 4. Intraoperative appearance of the cyst in the abdominal Wall.

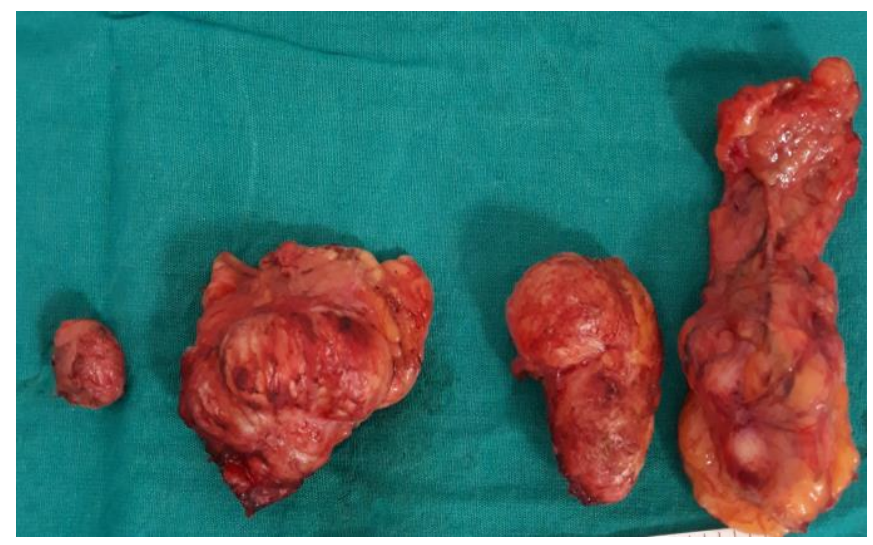

Figure 5. Total cystectomy materials in the abdominal wall and intraabdominal and subdiaphragmatic areas. 


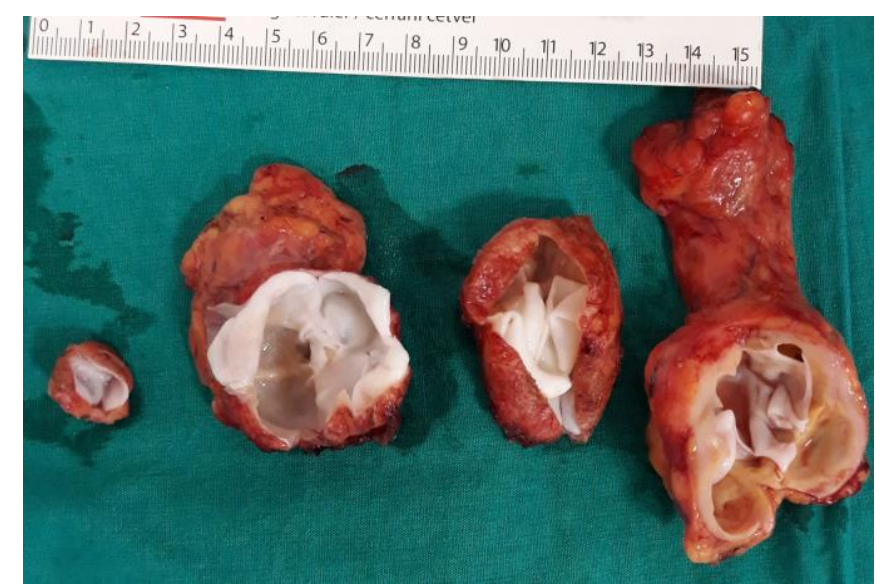

Figure 6. Appearance of germinative membranes in total cystectomy specimens.

\section{DISCUSSION}

Local recurrence during the long-term followup of HD remains an important problem. Recurrence is defined as reappearance of live cysts following the treatment of an intra- or extra-hepatic disease. Local recurrence rarely occurs following complete resection of an intact cyst and often results from the spillage of live parasites or leaving a residual cyst wall containing germinative membrane, daughter vesicles, or protoscolices during surgery 3,6 . Factors affecting recurrence include large cyst size, conservative treatment, laparoscopic surgery, and experience of the surgeon ${ }^{4-8}$. Recurrent extrahepatic disease caused by procedure-related spillage is often preventable. During the procedure, an adequate surgical field of view can be secured with a good preoperative planning, minimal cyst mobilization, and avoidance of perforation. Scolicidal agent-soaked sponges can be placed in both the incision site and all the anatomical pericystic areas. Care needs to be taken during the initial aspiration due to high intracystic pressure. The use of scolicidal agents in conservative treatment is highly important. Following the injection of the scolicidal agent into the cyst, a 10-minute waiting period should be allowed. However, the effectivity of the scolicidal agent is relatively lower in multivesicular and large cysts. Moreover, although the use of scolicidal agents at appropriate concentrations and adequate doses is mandatory, it cannot replace meticulous surgical treatment ${ }^{9}$.

Surgical planning of HD treatment is based on the localization and number of cysts, presence of cysts with infection, and rupture into biliary tract. The incidence of recurrence is lower after radical surgeries; however, conservative treatments are performed more commonly due to their lower morbidity rates. Adhesions caused by prior surgery further complicate the surgical procedure. The incidence of rerecurrence after recurrence surgery can be as high as $27 \%$. Therefore, mechanical clearance of whole alive cystic material is highly important. Perioperative albendazole treatment has been reported to reduce the recurrence rate from $18.7 \%$ to $4.1 \%$ and is highly recommended. In recurrent cases, in particular, administration of intraoperative ultrasonographic examination reduces the risk of residue cysts $2,10,11$.

\section{CONCLUSION}

Spillage occurring during the surgical management of hydatid cyst of the liver is a preventable cause of extrahepatic recurrence. However, surgical management of recurrence associated with procedure-related spillage is further complicated by the multifocal nature of these cysts and the adhesions caused by prior surgery. The recurrence risk can be reduced via perioperative albendazole treatment, complete resection of the cyst without perforation, protection of adjacent anatomical structures by the use of scolicidal agent-soaked sponges, administration of intraoperative USG, and meticulous surgical treatment leaving no residual cyst material.

Conflicts of interest: The authors have no conflict of interests to declare. 
Financial Disclosure: The authors declared that this study has received no financial support.

\section{REFERENCES}

1. Bahce ZS, Akbulut S, Aday U, Demircan F, Senol A. Cutaneous fistulization of the hydatid disease: A PRISMA-compliant systematic review. Medicine. 2016; 95: .

2. Brunetti E, Kern P, Vuitton DA. Writing Panel for the WHO-IWGE. Expert consensus for the diagnosis and treatment of cystic and alveolar echinococcosis in humans. Acta Trop. 2010; 114: 1-16.

3. Sielaff TD, Taylor B, Langer B. Recurrence of hydatid disease. World J Surg. 2001; 25: 83-6.

4. Jerraya H, Khalfallah M, Osman SB, Nouira R, Dziri C. Predictive factors of recurrence after surgical treatment for liver hydatid cyst. SurgEndosc. 2015; 29: 86-93.

5. Velasco-Tirado V, Romero-Alegría Á, BelhassenGarcía M, et all. Recurrence of cystic echinococcosis in an endemic area: a retrospective study. BMC Infect Dis. 2017; 17: 455.
6. Kapan M, Kapan S, Goksoy E, Perek S, Kol E. Postoperative recurrence in hepatic hydatid disease. J Gastrointest Surg 2006; 10: 734-9.

7. E Malki HO, E Mejdoubi Y, Souadka A, et all. Does primary surgical management of liver hydatid cyst influence recurrence?. J Gastrointest Surg. 2010; 14: 1121-27.

8. Aydin U, Yazici P, Onen Z, et all. The optimal treatment of hydatid cyst of the liver: radical surgery with a significant reduced risk of recurrence. Turk J Gastroenterol. 2008; 19:33-9.

9. Malik A. A, ul Bari S. Surgical Management of Hydatid Liver Disease. In Human Abdominal Hydatidosis. Springer, Singapore. 2019; 37-54.

10. Prousalidis J, Kosmidis C, Anthimidis G, et all. Postoperative recurrence of cystic hydatidosis. Can J Surg. 2012; 55: 15-20.

11. Arif SH, Shams-U-Bari, Wani NA, et all. Albendazole as an adjuvant to the standard surgical management of hydatid cyst liver. Int J Surg 2008; 6: 448-51. 